\title{
Penguatan Motivasi dan Kapasitas Para Pendamping Disabilitas Gantiwarno Klaten Melalui Pelatihan Pembuatan Keripik Ubi Ungu SLB-BC Bhakti Putra Bahagia, Kecamatan Gantiwarno, Kabupaten Klaten, Provinsi Jawa Tengah
}

\section{Siti Azizah Susilawati*1, Yovi Annang Setiyawan², Faizah Laila Oktaviana3, Tata Aulia Wardani ${ }^{4}$, Sekar Kinasih Ningrum Prambudi5, Sri Murdiyanti6}

\author{
1,5Program Studi Pendidikan Geografi, Fakultas Keguruan dan Ilmu Pendidikan, Universitas \\ Muhammadiyah Surakarta, Indonesia \\ 2,3Pendidikan Akuntansi, Fakultas Keguruan dan Ilmu Pendidikan, Universitas Muhammadiyah Surakarta, \\ Indonesia \\ 4,6Pendidikan Kewarganegaraan, Fakultas Keguruan dan Ilmu Pendidikan, Universitas Muhammadiyah \\ Surakarta, Indonesia \\ *e-mail: azizah.susilawati@ums.ac.id ${ }^{1}$, a210180211@student.ums.ac.id ${ }^{2}$, \\ a210180155@student.ums.ac.id ${ }^{3}, \underline{\text { tataauliaw20@gmail.com }}^{4}$, kinasihwidayat@gmail.com ${ }^{5}$, \\ srimurdiyanti522@gmail.com ${ }^{6}$
}

\begin{abstract}
Abstrak
Pengabdian ini bertujuan untuk meningkatkan kapasitas secara ekonomi dengan meningkatkan pendapatan keluarga pendamping disabilitas melalui keterampilan membuat snack berupa keripik ubi ungu. Pelatihan pembuatan keripik ubi ungu ini dilaksanakan di halaman SLB-BC Bhakti Putra Bahagia, Kecamatan Gantiwarno, Kabupaten Klaten. Diharapkan dengan adanya pelatihan ini dapat menambah pendapatan keluarga disabilitas melalui pendamping. Metode pengabdian ini adalah pendampingan membuat keripik ubi ungu dan dilanjutkan dengan praktik pembuatan keripik secara mandiri dan terkontrol melalui monitoring dan evaluasi yang dilakukan oleh Tim, pihak sekolah dan PPDK Kabupaten Klaten. Hasil dari pelatihan ini adalah : (1) Sebanyak 86\% peserta mengetahui keripik ubi ungu. (2) Sebanyak 93\% peserta tidak mengetahui proses pembuatan keripik ubi ungu. (3) Seluruh peserta tidak pernah membuat keripik ubi ungu. (4) Sebanyak 86\% mengetahui peluang usaha keripik ubi ungu. Berdasarkan hasil tersebut maka pelatihan pembuatan keripik ubi ungu memiliki peluang dan motivasi usaha yang baik bagi peserta dalam memajukan perekonomian.
\end{abstract}

Kata kunci: Disabilitas, Peluang Usaha, Perekonomian

\begin{abstract}
This service aims to increase economic efficiency by increasing the income of families with disabilities through the ability to make snacks in the form of purple sweet potato chips. The training course for making purple potato chips was held at the SLB-BC Bhakti Putra Bahagia site in the Gantiwarno district of Klaten Regency. This mentoring education is expected to increase the income of families with disabilities. This service method supports the production of purple sweet potato chips, continues to practice homemade chips, and is managed by teams, schools, and monitoring and evaluation by the PPDK Klaten Regency. The results of this training are as follows: (1) Up to $86 \%$ of participants are familiar with purple sweet potato chips. (2) 93\% of the participants were unfamiliar with the manufacturing process of purple potatoes. (3) No athlete has made purple yam chips. (4) $86 \%$ know the business opportunity for purple sweet potato chips. Based on these results, purple sweet potato chip manufacturing training provides participants with great business opportunities and motivation to grow their economy.
\end{abstract}

Keywords: Business Opportunity, Disability, Economy

\section{PENDAHULUAN}

Bencana gempa bumi yang menimpa Kecamatan Gantiwarno Kabupaten Klaten tahun 2006 menyebabkan banyak yang mengalami disabilitas. Menurut Undang-Undang Negara Republik Indonesia Nomor 4 Tahun 1997 Tentang Penyandang Cacat, disebutkan bahwa disabilitas atau kecacatan adalah setiap orang yang mempunyai kelainan fisik dan/atau mental yang dapat mengganggu atau merupakan rintangan dan hambatan untuk melakukan kehidupan 
secara selayaknya. Menurut Kamus Besar Bahasa Indonesia (KBBI) penyandang diartikan sebagai menyandang (menderita) sesuatu sedangkan disabilitas diartikan sebagai keadaan seperti sakit maupun cidera yang dapat menghalangi atau membatasi kemampuan mental dan fisik seseorang. Penyandang disabilitas digolongkan sebagai kelompok yang rentan karena sering menerima perlakuan diskriminasi dari lingkungan sekitar serta banyak hak-hak dari penyandang disabilitas yang tidak terpenuhi. Mental dan fisik seseorang atau dapat diartikan juga dengan suatu keadaan yang dialami seseorang sehingga tidak dapat melakukan hal-hal seperti biasa (Ndaumanu, 2020).

Para disabilitas perlu memiliki pendamping untuk menjalankan aktivitas sehari-harinya. Edi Suharto dalam (Mardiyati, 2017) mengartikan pendamping sosial sebagai agen yang bertugas untuk mendampingi masyarakat yang tidak berdaya disebabkan karena hambatan internal dan eksternal. Pendamping disabilitas memiliki kewajiban dan tugas yang penting mulai dari bentuk pertolongan hingga terjadi perubahan pada yang didampingi, keluarga penyandang disabilitas, serta masyarakat secara umum. Pendamping tersebut merupakan orang yang akan menuntunnya untuk melakukan aktivitas. Pendamping mempunyai peran penting dalam kehidupan mereka, dimana pendamping harus meluangkan waktu untuk mengurusnya. Selain itu pendamping harus memberikan semangat bagi disabilitas untuk selalu melakukan hubungan sosial dengan masyarakat inklusi. Masyarakat inklusi adalah masyarakat universal tanpa mengenal perbedaan suku, agama, ras dan ideologi (Mulyati et al., 2019).

Pendamping harus memiliki waktu perhatian yang lebih banyak untuk keluarganya yang mengalami disabilitas, sehingga mereka tidak dapat bekerja dengan maksimal untuk memenuhi kebutuhan keluarganya. Berdasarkan permasalahan tersebut maka pengabdian ini dilaksanakan berupa pelatihan pembuatan keripik ubi ungu. Pelatihan ini diperuntukkan bagi pendamping disabilitas yang berada di Kecamatan Gantiwarno, Kabupaten Klaten.

Pelatihan pembuatan keripik ubi ungu ini didasarkan pada hasil observasi di lapangan dimana ubi ungu merupakan salah satu komoditi yang berada di wilayah Gantiwarno yang belum dikembangkan secara maksimal. Ubi ungu merupakan salah satu tanaman yang mengandung antioksidan yang tinggi (Salim et al., 2017). Pelatihan pembuatan kripik ubi ungu ini dalam pengolahannya membutuhkan waktu yang tidak lama, namun perubahan bentuk dari ubi ungu mentah menjadi keripik dapat meningkatkan nilai tambah ekonomis dari ubi ungu tersebut. Pelatihan ini juga memberikan pengetahuan tambahan berupa pemasaran yang baik dan menggunakan media digital akan berpengaruh terhadap penjualan dan keuntungan didapat. "Memaksimalkan pemasaran dapat menambah volume penjualan sehingga nilai tambah yang diperoleh dapat lebih besar dari tahun ke tahun" (Risal \& Djadid, 2014).

Tujuan pengabdian ini adalah untuk meningkatkan kapasitas secara ekonomi dengan meningkatkan pendapatan keluarga pendamping disabilitas melalui keterampilan membuat snack berupa keripik ubi ungu. Sasaran pengabdian ini adalah ibu-ibu pendamping disabilitas yang sebagian besar adalah orangtua disabilitas dengan status ibu rumah tangga.

\section{METODE}

Pelatihan pembuatan keripik ubi ungu dilaksanakan di halaman SLB-BC Bhakti Putra Bahagia, Kecamatan Gantiwarno, Kabupaten Klaten, Provinsi Jawa Tengah. Pelatihan ini kami pilih berdasarkan hasil diskusi bersama Ketua Paguyupan Penyandang Disabilitas Klaten (PPDK). Pelatihan pembuatan keripik ubi ungu melibatkan orang tua anak berkebutuhan khusus atau disabilitas. Kegiatan ini dilaksanakan bertujuan untuk meningkatkan kapasitas secara ekonomi dengan meningkatkan pendapatan keluarga pendamping disabilitas melalui keterampilan membuat snack berupa keripik ubi ungu. Metode pengabdian ini adalah pendampingan membuat keripik dan dilanjutkan dengan praktik pembuatan keripik secara mandiri dan terkontrol. Monitoring dan evaluasi dilakukan oleh Tim, pihak sekolah, dan PPDK Kabupaten Klaten. 


\subsection{Pendampingan}

Pendampingan berupa pelatihan diselenggarakan oleh TIM PHP2D (Program Holistik Pembinaan dan Pemberdayaan Desa) HMP Pendidikan Geografi FKIP UMS berkolaborasi dengan HMP Pendidikan Akuntansi dan HMP Pendidikan Kewarganegaraan, Fakultas Keguruan dan Ilmu Pendidikan, Universitas Muhammadiyah Surakarta pada hari Minggu, 31 Oktober 2021. Pelatihan ini mendatangkan narasumber yang ahli dalam bidang pembuatan keripik yaitu pemilik usaha dagang keripik yang ada di Kabupaten Boyolali. Kegiatan ini memerlukan sarana dan prasarana seperti halaman SLB-BC Bhakti Putra Bahagia, peralatan memasak, alat penggiling dan alat press kemasan yang telah disiapkan oleh Tim.

Rangkaian kegiatan pelatihan pembuatan keripik ubi ungu diawali dengan pengisian kuesioner untuk mengetahui sejauh mana pemahaman peserta mengenai pembuatan keripik ubi ungu, setelah itu kegiatan pelatihan dibuka dengan beberapa sambutan. Sambutan pertama oleh Ketua Tim PHP2D, sambutan kedua oleh Dosen Pembimbing, sambutan ketiga oleh Kepala SLBBC Bhakti Putra Bahagia, dan sambutan terakhir oleh Ketua PPDK. Setelah sambutan selesai, kegiatan pelatihan pembuatan keripik ubi ungu langsung dilanjutkan dengan praktik pembuatan keripik ubi ungu yang didampingi secara langsung oleh pembicara. Dalam kegiatan praktik, peserta diberi buku petunjuk pembuatan keripik ubi ungu. Pada buku panduan sudah dijelaskan tahap-tahap pembuatan beserta takaran yang diperlukan pada pembuatan keripik ubi ungu. Praktik pelatihan pembuatan keripik ubi ungu dilaksanakan melalui beberapa tahap yang meliputi pembuatan adonan, membentuk adonan dan menggoreng keripik hingga tahap pengemasan. Pada praktiknya peserta diberi kebebasan untuk bertanya langsung kepada pembicara mengenai detail proses pembuatan keripik ubi ungu. Hal tersebut dikarenakan agar peserta bisa melakukan pembuatan ubi ungu untuk membuka usaha dagang.

\subsection{Praktik Secara Mandiri dan Terkontrol}

Pengabdian pembuatan keripik ubi ungu ini selanjutnya dilakukan tindaklanjut berupa praktik secara mandiri oleh ibu-ibu pendamping disabilitas pada hari Minggu 7 November 2021. Praktik secara mandiri dilakukan dengan pendampingan dari pihak sekolah dan tim PPDK Kabupaten Klaten dengan pemantauan dari tim PHP2D. Pelatihan ini dilanjutkan sudah diagendakan kembali untuk dilakukan oleh ibu-ibu pendamping disabilitas secara rutin dengan waktu yang telah disepakati dengan pihak sekolah dan PPDK Kabupaten Klaten.

\section{HASIL DAN PEMBAHASAN}

\subsection{Hasil}

Kegiatan pelatihan pembuatan keripik ubi ungu ini adalah salah satu cara Tim PHP2D Desa Mlese Kecamatan Gantiwarno dalam upayanya mengangkat UMKM dan Ekonomi para pendamping disabilitas. Pengolahan ubi ungu menjadi keripik sehingga mempunyai peningkatan secara ekonomis ini melalui tahapan berupa keripik ubi ungu dengan alur pembuatan seperti yang ditunjukkan pada Gambar 1.

Pelaksanaan pelatihan pembuatan keripik ubi ungu ini kami melalui beberapa tahap yang diantaranya:

1. Tahapan Persiapan

Pada tahap ini kami melakukan survey ke Tempat produksi keripik ubi ungu yang terletak di Kecamatan Sambi, Kabupaten Boyolali, Jawa Tengah. Dalam Proses pembuatan keripik ubi ungu ini sudah menggunakan alat alat yang modern seperti alat penggiling, alat press, dan proses pembuatannya.

2. Sosialisasi Program

Pada Tahap ini, kami mensosialisasikan program Tim PHP2D kepada mitra pengabdian yang dilaksanakan di Desa Mlese, Kecamatan Gantiwarno, Kabupaten Klaten. Sasaran program kami adalah ibu-ibu pendamping disabilitas. Program yang kami 
laksanakan adalah pelatihan pembuatan keripik yang berguna meningkatkan ekonomi ibu ibu pendamping disabilitas Gantiwarno Klaten.

3. Alat Penunjang Kegiatan

Sosialisasi pengabdian yang kami lakukan mendapatkan hasil terdapat kebutuhan dari proses pembuatan keripik ubi ungu. Kebutuhan tersebut ditujukan untuk menopang produksi keripik ubi ungu. Kebutuhan tersebut diantaranya mesin penggiling, timbangan, alat press plastik, kemasan keripik dan alat pendukung lainnya.

Mesin penggiling digunakan untuk menggiling adonan keripik hingga berbentuk pipih kemudian dipotong untuk dibentuk. Dengan adanya mesin penggiling ini dapat mempersingkat waktu dalam memipihkan adonan, sehingga mampu meningkatkan jumlah produksi pembuatan keripik ubi ungu. Timbangan adonan digunakan untuk menimbang adonan seperti tepung terigu, mentega, gula pasir, dengan adanya alat bantu timbangan adonan ini mempermudah dalam proses produksi tanpa harus mengira-ira takaran adonan.

Alat Press Plastik digunakan untuk merekatkan kemasan keripik semi otomatis, mempermudah proses pengemasan produk, kemasan menjadi terlihat lebih rapi, menjaga kontaminasi sehingga produk lebih tahan lama dan higienis. Kemasan Produk keripik ubi ungu menggunakan plastik dengan desain produk semenarik mungkin guna mendapatkan perhatian dari konsumen dan proses pemasaran. Alat pendukung lainnya seperti pisau, cobek, baskom, kompor, dan penggorengan digunakan untuk proses pembuatan keripik ubi ungu.

4. Pelaksanaan Pembuatan Keripik Ubi Ungu

Pelatihan pembuatan keripik ubi ungu dimulai dengan penjelasan dari narasumber yaitu bapak Rujito yang berprofesi sebagai pengrajin keripik ubi ungu kemudian dilanjutkan dengan praktik secara berkelompok oleh ibu-ibu pendamping disabilitas dengan didampingi tim PHP2D. Pelatihan pembuatan ubi ungu dilakukan dengan tahapan pembuatan kripik ubi ungu sesuai pada Gambar 1.

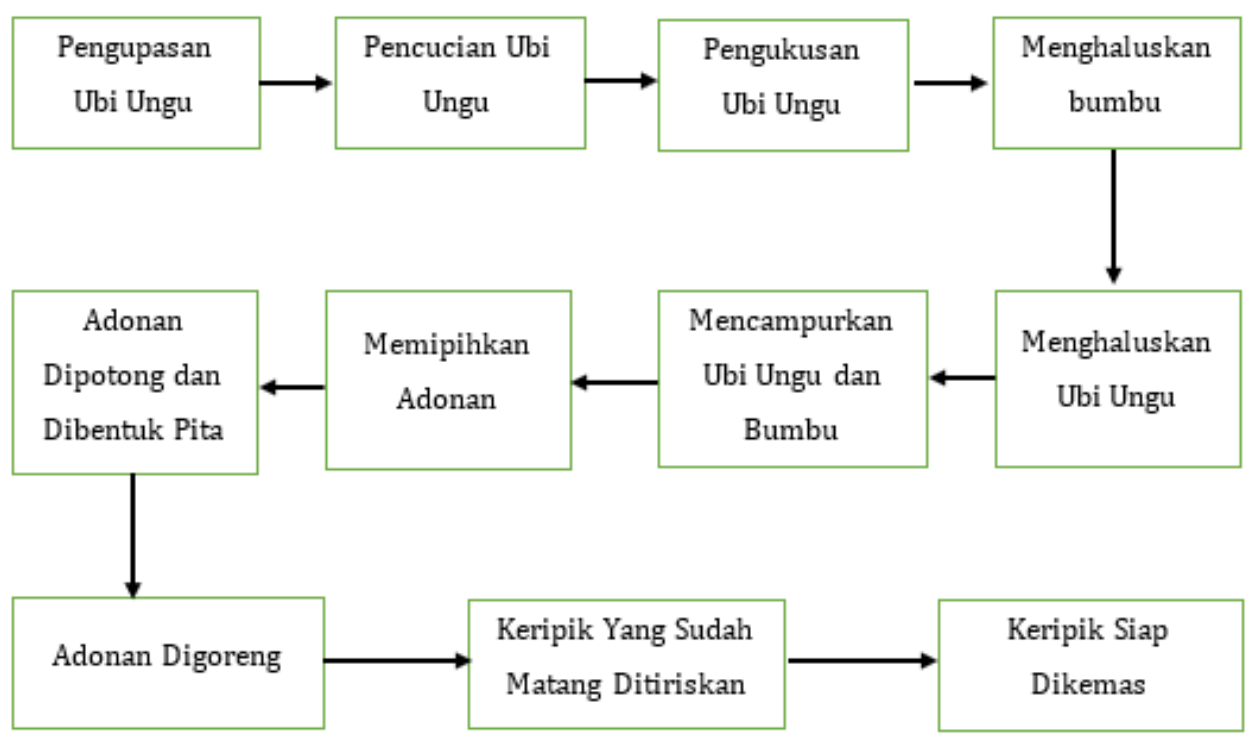

Gambar 1. Langkah-langkah Pembuatan Kripik Ubi Ungu

Sumber : Tim PHP2D 2021

\subsection{Pembahasan}

Pelaksanan pelatihan yang dilakukan di SLB-BC Bhakti Putra Bahagia Gantiwarno ini mendapatkan sambutan dan antusiasme yang tinggi dari teman-teman disabilitas dan para ibu ibu pendamping disabilitas. Hal ini dapat terlihat pada saat pemateri menjelaskan proses pembuatan keripik ubi ungu dan pada saat praktik pembuatan keripik. 


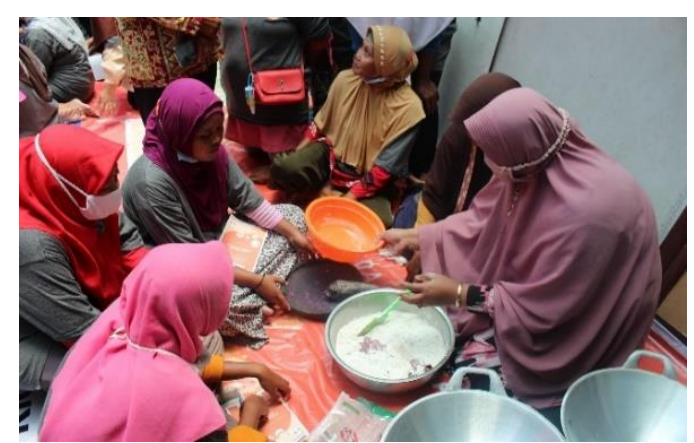

Gambar 2. Proses Pembuatan Keripik Ubi Ungu Sumber : Dokumentasi Tim PHP2D

Gambar diatas merupakan aktifitas ibu-ibu pendamping disabilitas pada saat praktik secara berkelompok. Pelatihan terbagi menjadi 3 kelompok sesuai dengan alat dan bahan yang telah disediakan oleh tim PHP2D. Pengukuran terhadap pengabdian ini dapat diketahui dari hasil kuisioner yang diberikan kepada ibu-ibu peserta guna mengetahui sejauhmana ketertarikan dan pemahaman peserta mengenai pelatihan pembuatan keripik ubi ungu ini.

Pelatihan pembuatan keripik ubi ungu dilakukan dengan antusias oleh peserta, pihak sekolah dan tim PPDK Kabupaten Klaten. Pelatihan berupa praktik ini dilakukan dimulai dengan tahapan pembuatan keripik sampai pada tahapan pengemasan keripik. Berikut hasil keripik ubi ungu yang dihasilkan oleh ibu-ibu peserta pelatihan.
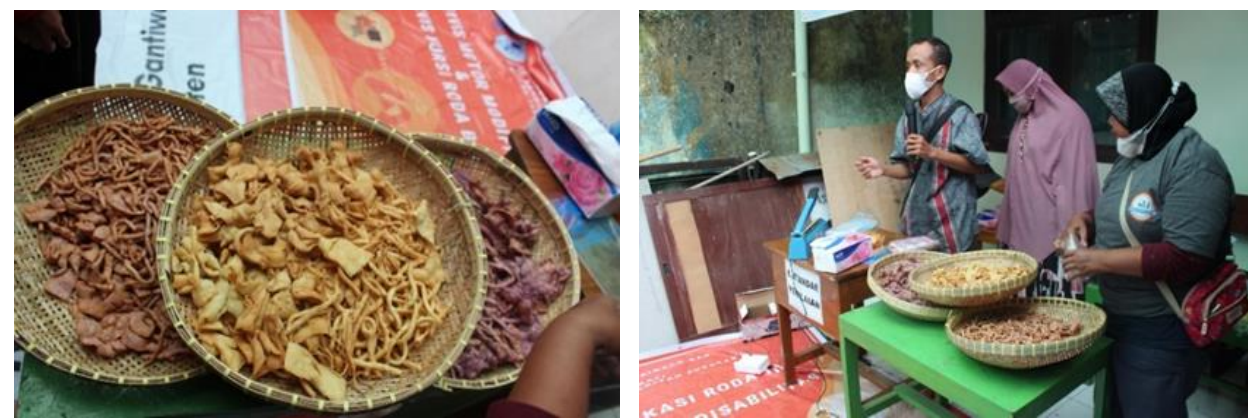

Gambar 3. Keripik Ubi Ungu Hasil Pelatihan

Sumber : Dokumentasi Tim PHP2D

Pelatihan pembuatan keripik ubi ungu ini dilanjutkan sampai tahap pengemasan keripik. Pengemasan produk keripik ubi ungu menggunakan kemasan standing pouch dengan disertai stiker yang telah didesain oleh Tim PHP2D.

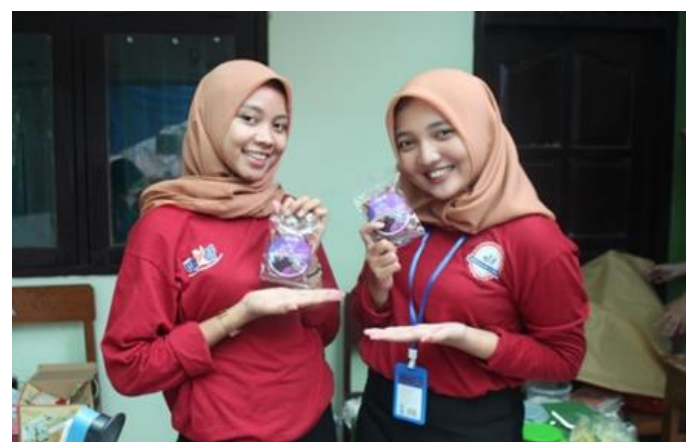

Gambar 4. Keripik Ubi Ungu dengan Kemasan yang Menarik Sumber : Dokumentasi Tim PHP2D

Hasil dari analisis kuesioner terhadap informasi yang diketahui oleh ibu-ibu peserta pelatihan terhadap keripik ubi ungu menunjukkan bahwa peserta pelatihan ini sebanyak $86 \%$ 
sudah mengetahui atau mendengar tantang keripik ubi ungu, sebanyak $14 \%$ belum mengetahui tentang keripik ubi ungu, dengan demikian sebagian besar dari peserta sudah pernah mendengar mengenai keripik ubi ungu sehingga memudahkan peserta dalam proses pembuatan keripik ubi ungu ini.

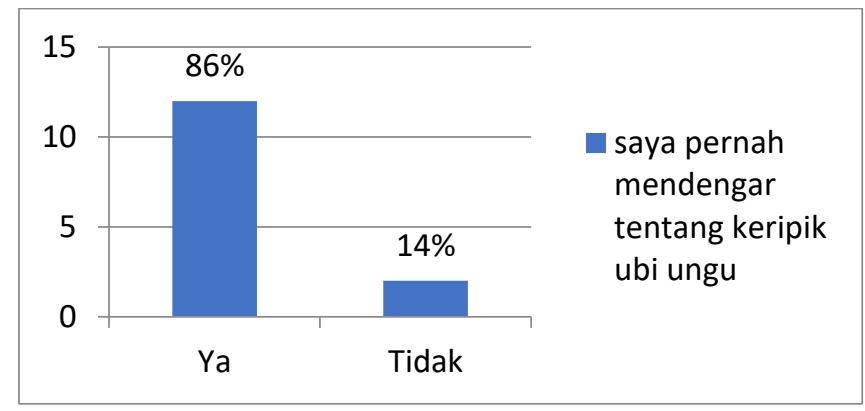

Gambar 5. Informasi tentang Keripik Ubi Ungu

Sumber: Tim PHP2D 2021

Hasil analisis dari Gambar 6 diketahui bahwa peserta masih belum mengetahui proses pembuatan keripik ubi ungu. Hasil dari kuesioner yang Tim PHP2D berikan kepada peserta terdapat $7 \%$ saja yang mengetahui proses pembuatan keripik ubi ungu, dan sebanyak 93\% masih belum mengetahui proses pembuatan keripik ubi ungu, dengan demikian masih banyak dari peserta yang belum mengetahui cara mengolah ubi ungu menjadi makanan yang iconic pada era saat ini.

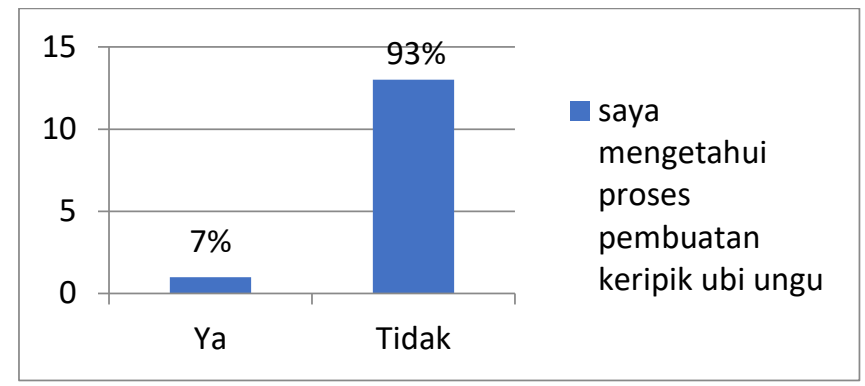

Gambar 6. Proses Pembuatan Keripik Ubi Ungu

Sumber: Tim PHP2D 2021

Berdasarkan Gambar 7 diketahui bahwa peserta belum pernah membuat keripik ubi ungu. Dilihat dari kuesioner yang dibagikan Tim PHP2D kepada peserta pelatihan keripik ubi ungu $100 \%$ peserta belum pernah membuat keripik ubi ungu. Dengan demikian dengan diadakannya pelatihan ini mampu membuat para peserta mengetahui cara membuat keripik ubi ungu yang diharapkan mampu menjadi salah satu inovasi para peserta untuk menjadikan peluang usaha.

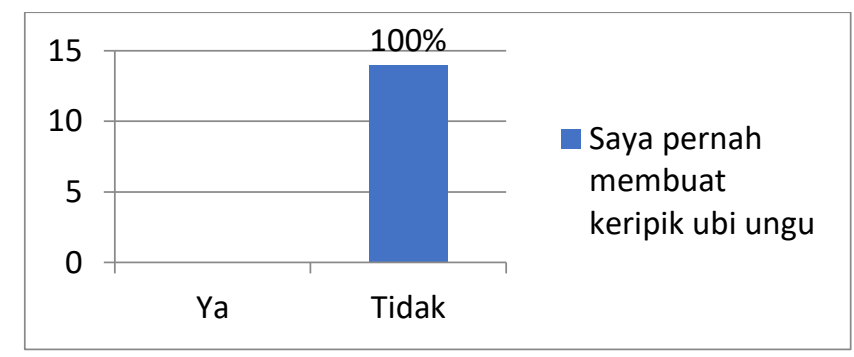

Gambar 7. Pembuatan Keripik Ubi Ungu Sumber: Tim PHP2D 2021

Hasil dari analisis Gambar 8 dibawah ini dapat diketahui bahwa peserta belum mengetahui peluang usaha pembuatan keripik ubi ungu. Dilihat dari kuisioner yang diberikan 
Tim PHP2D kepada peserta dapat diketahui bahwa sebanyak 14\% belum mengetahui peluang usaha keripik ubi ungu, sebanyak $86 \%$ mengetahui peluang usaha keripik ubi ungu. Dengan demikian setelah diadakannya pelatihan keripik ubi ungu ini dapat menjadi motivasi peserta untuk menjadikan peluang ini sebagai salah satu cara dalam memajuakan perekonomian peserta sendiri.

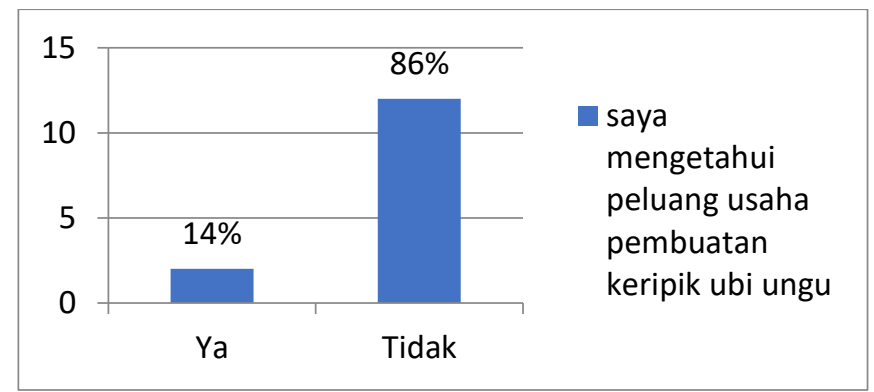

Gambar 8. Peluang Usaha Keripik Ubi ungu

Sumber: Tim PHP2D 2021

Berdasarkan pada hasil kuesioner yang telah dijawab oleh ibu-ibu peserta pelatihan dapat ditarik kesimpulan bahwa pelatihan ini menunjukan peluang dan motivasi bagi para peserta untuk menjadikan keripik ubi ungu sebagai cara memajukan perekonomian peserta. Sebagian peserta setuju bahwa keripik ubi ungu ini adalah salah satu inovasi terbaru untuk mereka sehingga mereka berantusias untuk memproduksi ubi ungu ini secara berkala. Terdapat evalusi dalam pelatihan keripik ubi ungu ini yang mana masih kurangnya waktu dalam pelatihan sehingga pelatihan yang diselenggarakan oleh Tim PHP2D kurang maksimal.

\section{KESIMPULAN}

Hasil analisis data di atas dapat disimpulkan bahwa sebanyak $86 \%$ peserta mengetahui keripik berbahan dasar dari ubi ungu. Sedangkan dalam proses pembuatan keripik ubi ungu ini sebanyak 93\% peserta tidak mengetahuinya dan dari seluruh peserta yang mengikuti kegiatan ini tidak pernah membuat keripik ubi ungu. Sehingga dengan mengikuti pelatihan ini peserta dapat menciptakan peluang usaha dengan membuat keripik ubi ungu ini karena dari hasil analisis data sebanyak $86 \%$ yakin bahwa keripik ubi ungu ini memiliki peluang usaha yang menjanjikan.

\section{DAFTAR PUSTAKA}

Arifin. Mohammad, D. (2019). "Pemberdayaan Masyarakat Desa Paris Mootilango Gorontalo Melalui Pendampingan Budidaya Bawang Dayak." Jurnal Pengabdian Kepada Masyarakat "INSAN CITA," 4-8.

Emrizal. (2015). Pemulihan Ekonomi Dengan Usaha Mikro Pasca Gempa Dan Tsunami Tahun 2009 Di Sumatera Barat. SNEMA-2015, 81-86.

Jufri. Muhammad, G. (2019). "Pemberdayaan Masyarakat Melalui Olahan Keripik Pisang Membagu Kelompok Home Industri Menuju Masyarakat Sejahtera Di Kecamatan Sindue Tobata." Jurnal Inovasi Pengabdian Masyarakat, 2(2), 34.

Mardiyati, A. (2017). Peran Pendamping Berbasis Masyarakat Bagi Penyandang Disabilitas Dalam Membangun Kemandirian. 133-144.

Mulyati, T., Rohmatiah, A., \& Amadi, D. N. (2019). Pelatihan Dan Pendampingan Penyandang Disabilitas Desa Simbatan, Kecamatan Nguntoronadi Kabupaten Magetan. Jurnal Terapan Abdimas, 4(2), 187. https://doi.org/10.25273/jta.v4i2.4844

Ndaumanu, F. (2020). Hak Penyandang Disabilitas : Antara Tanggung Jawab dan Pelaksanaan 
Oleh Pemerintah Daerah.

Risal, M., \& Djadid, N. K. (2014). Analisis Nilai Tambah Ekonomis Pada Industri Rumah Tangga "Berhias" di Kota Palopo. Jurnal Manajemen, 01(02), 26-38.

Salim, M., Dharma, A., Mardiah, E., \& Oktoriza, G. (2017). Pengaruh Kandungan Antosianin Dan Antioksidan Pada Proses Pengolahan Ubi Jalar Ungu. Jurnal Zarah, 5(2), 7-12. https://doi.org/10.31629/zarah.v5i2.209

Setiawan, D. (2018). "Pemberdayaan Masyarakat Olahan Es Krim Kulit Pisang Di Desa Jogosatru". Jurnal Pengabdian Masyarakat, 1, 2.

Yusiana, E. (2018). Pembuatan Keripik Ubi Aneka Rasa oleh Kelompok Wanita Tani Harapan Baru di Distrik Walelagama, Jayawijaya, Papua. Jurnal Ilmiah Pengabdian Kepada Masyarakat, 4(2), 92-97. 